\title{
Distributional patterns of fecal indicator bacteria in spring area of Plitvice Lakes National park
}

\section{VURNEK MAJA ${ }^{1}$ \\ BROZINČEVIĆ ANDRIJANA ${ }^{1}$ \\ BRIŠKI FELICITA ${ }^{2}$ \\ MATONIČKIN KEPČIJA RENATA ${ }^{3}$ \\ ${ }^{1}$ Public Institution Plitvice Lakes National Park, Scientific Research Center „Ivo Pevalek”, Josipa Jovića 19, HR - 53231 Plitvice Lakes \\ ${ }^{2}$ Faculty of Chemical Engineering and Technology, Division of Industrial Ecology, University of Zagreb, Marulićev trg 19, HR - 10000 Zagreb \\ ${ }^{3}$ Faculty of Science, Department of Biology, University of Zagreb, Rooseveltov $\operatorname{trg} 6$, HR - 10000 Zagreb}

\section{Correspondence:}

Maja Vurnek

e-mail:maja.vurnek@np-plitvicka-jezera.hr

Key words: total coliforms, fecal coliforms, FC/FS ratio, Pseudomonas aeruginosa, source streams, lake, protected area
Received November 20, 2014.

Revised March 02, 2016.

Accepted March 03, 2016

\begin{abstract}
Background and purpose: Fecal indicator bacteria (FIB) have widespread use as indicators of water quality and health hazards. The purpose of this study was to determine distributional patterns of FIB and to assess their origin on several sites in spring area and in vertical profile of Prošćansko Lake in Plitvice Lakes National Park.
\end{abstract}

Materials and Methods: The study was conducted from March to January 2013 on 9 sampling sites. Standard microbiological methods were used to determine densities of total coliforms (TC), fecal coliforms (FC), fecal streptococcus (FS), Pseudomonas aeruginosa (PS) and Clostridium perfringens in water samples.

Results and Conclusions: Source area sustained higher densities of FIB compared to Prošćansko Lake, throughout the study period. Sampling site White River below the village had highest values of certain FIB, indicating Plitvički Ljeskovac as main fecal pollution source. There were seasonal differences in TC and FC with July and October displaying increased densities, the latter probably due to heavy rainfall. The ratio FC/FS in July indicated contamination of mainly animal origin. At the sampling site of Matica River estuary in Prošćansko Lake, an increased densities of TC and FC bacteria were observed compared to other sites and depths, possibly due to source streams influence and stratification conditions. This study showed that the indicator bacteria of fecal contamination in the spring area of the Plitvice Lakes National Park are present and their quantity and distribution patterns depend on season, weather conditions and different effects in water column of the lake.

\section{INTRODUCTION}

$\mathbf{B}$ acteria are widespread throughout the freshwater environment, B forming extensive pelagic and benthic populations in a wide range of habitats including mudflats, bogs, sulphur springs, lakes and rivers. Most freshwater bacteria show close physiological adaptations to their environment (1).

The coliform group of bacteria is considered to be the main indicator of water quality for domestic usage, industry and other needs (2). Special attention has been paid to Gram-negative rods belonging to the family Enterobacteriaceae that are found worldwide, representing a major component of the facultatively anaerobic intestinal flora of humans and animals, some of which are associated with human disease (3). When fecal streptococcus bacteria (enterococci), the Gram positive and non- 
spore-forming are released from the gastrointestinal tract of warm-blooded animals into secondary habitats such as environmental waters, they are subjected to a host of biotic and abiotic factors (4). It was also recognized that in less contaminated water this group of bacteria comes along with some enteroviruses (5). Bacteria species like Pseudomonas can adapt to different environments and contaminate recreational waters (6) while the sulphite reducing bacteria Clostridium perfringens, also an indicator of fecal contamination, is naturally present in soil (7). In research conducted in subtropical area $C$. perfringens remained in the river for long periods but was not capable of growth. Research is considering the fact that this bacterium is very useful for determining the ultimate fate of sewage and storm water impacts (8).

Processes of dispersion, dilution, horizontal and vertical transport determines the distribution of pathogens in lakes and reservoirs. Horizontal transport is driven by inflows and basin-scale circulation patterns including wind-driven currents and internal waves. Also, the riverine inflow is considered to be the major source of pathogens (9). Recent research on indicator bacteria for evaluation of source water quality, water and wastewater treatment efficiency, distribution system contamination, possible health effects and possible presence or absence of pathogens suggests the use of four indicators: E. coli, enterococci, coliphages and Clostridium perfringens (10).

The Plitvice Lakes National Park is one of the oldest and largest protected areas in Croatia with the total surface of around $300 \mathrm{~km}^{2}$. National Park was inscribed on the UNESCO World Heritage List in 1979 due to its biological, geological and other natural values. Settled in a part of Dinaric karst area, the Park is characterized by karst sources, streams and rivers, but by far the most interesting part are the 16 cascading lakes created by tufa depositions in form of barriers. Tufa, is a common term for calcite layers in freshwater systems that are typical for late Quaternary, represents the product of calcium carbonate precipitation under the cool water (near ambient temperature) regime and typically contains the remains of micro and macrophytes, invertebrates and bacteria (11).

The spring area of Plitvice Lakes National Park which includes the sources of White and Black Rivers, their flow through the village Plitvički Ljeskovac and Matica River is also under different zones of protection determined through the Management Plan of National Park in order to protect this area from active tourism and additional anthropogenic influence.

First microbiological and chemical researches considering water quality of the spring area of the National Park began in the 1950s (12) and continued for many years. Even in that period, but especially in the 1970s, it was confirmed that the water and sediment of White River and Matica River were burdened with fecal material indicated by increased number of fecal indicator bacteria
(13). After the Homeland war, researches confirmed that the water quality of main supply rivers was significantly improved in a sense of a decrease in number of coliform bacteria (14). However, these researches have not included the assessment of fecal streptococcus bacteria and bacteria species Pseudomonas aeruginosa.

The objective of this study was (1) to determine a seasonal number of fecal indicator bacteria (FIB): total coliforms (TC), fecal coliforms (FC), fecal streptococcus (FS), Pseudomonas aeruginosa (PS) and Clostridium perfringens in spring area and in Prošćansko Lake; (2) calculate the FC/FS ratio with a purpose to determine the origin of fecal contamination at all sites and (3) to analyze distribution pattern of bacteria by vertical profile in Prošćansko Lake and possible influence of Matica River inflow.

\section{MATERIAL AND METHODS}

\section{Study area}

The catchment area of White and Black River is settled in the southwest and west parts of the Plitvice Lakes National Park, in the area of Jurassic and Cretaceous limestones with dolomites (15). The sources of White and Black River begin exactly in the area of contact between permeable and impermeable rocks. Both sources are of vouclusian type meaning they are inexhaustible and their water capacity varies between the spring maximum and the late autumn minimum (16). After the flow of both rivers through populated area of village Plitvički Ljeskovac with 20 residents (17), the rivers merge into the Matica River, which then flows into Prošćansko Lake.

The water samples were collected at 9 different sites: source of White River (WRs), White River above the village Plitvički Ljeskovac (WRa), White River below the village (WRb), source of Black River (BRs), Black River (BR), Matica River (MR) and Prošćansko Lake after the estuary of Matica River (PLe), in the middle of the lake (PLm) and at the deepest point of the lake (PLd). At the sites of Prošćansko Lake the water samples were collected at the depths of $1 \mathrm{~m}, 5 \mathrm{~m}, 10 \mathrm{~m}$ and $20 \mathrm{~m}$ (Figure 1). At the estuary of Matica River into Prošćansko Lake water samples were collected at the depths of $1 \mathrm{~m}, 5 \mathrm{~m}$ and 10 $\mathrm{m}$ due to the fact that this site is only about $12 \mathrm{~m}$ deep. At other sampling sites in the lake we collected samples at $1 \mathrm{~m}, 10 \mathrm{~m}$ and $20 \mathrm{~m}$ in order to have the exact number of samples at each sampling site in the lake (up to 3 samples) and because we were interested in bacteria dynamics in the upper part of the water column. The collection of water samples at the depth of $5 \mathrm{~m}$ was not included at two other sites (PLm and PLd) because our interest was to collect the results from water column from $1 \mathrm{~m}-20 \mathrm{~m}$, meaning just below the water surface, in the middle of water column $(10 \mathrm{~m})$ and at $20 \mathrm{~m}$. 

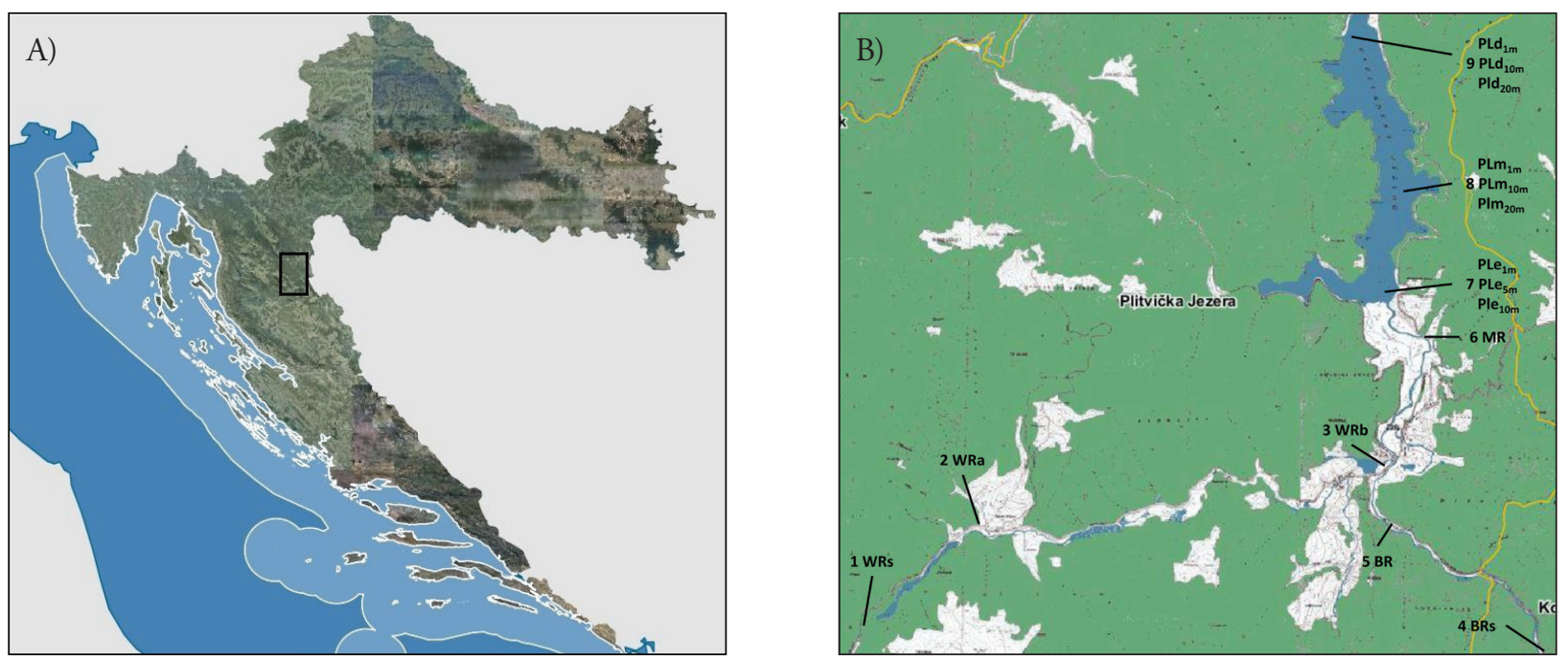

Figure 1. Position of Plitvice Lakes National Park in Croatia (A) (18) and sampling sites in the spring area (B). 1 source of White River (WRs), 2 White River above the village Plitvički Ljeskovac (WRa), 3 White River below the village Plitvicki Ljeskovac (WRb), 4 source of Black River (BRs), 5 Black River (BR), 6 Matica River (MR), and three sampling sites in Prošćansko Lake at different depths (PLe-7, PLm-8, PLd-9).

\section{Sampling and identification}

Sampling was carried out in the spring area of the Plitvice Lakes National Park in March, May, July and October of 2012 and in January 2013. At all sampling sites temperature, $\mathrm{pH}$ and electro-conductivity $(\mathrm{EC})\left(\mathrm{\mu S} \mathrm{cm}^{-1}\right)$ were measured by digital field multimeter (Wissenschaftlich-Technische Werkstätten, Germany). Dissolved oxygen (DO) $\left(\mathrm{mg} \mathrm{L}^{-1}\right)$ was determined with iodometric method by Winkler (2) and temperature in Prošćansko Lake with field instrument Seba Hydrometrie KLL-Q-2 (Germany). The water samples for microbiological analysis were collected into $500 \mathrm{~mL}$ sterile bottles under the water surface and with a plastic sampler Niskin type (Hydro-Bios, Germany) for water samples in the lake. Water samples were stored in the mobile fridge, and in two to three hours upon collecting they were processed in the laboratory of the Plitvice Lakes National Park. The data for FS and Pseudomonas aeruginosa were not obtained in March due to some technical difficulties with agar base.

All samples for microbiological analysis of FIB were processed using the filtration method according to standard methods (2) and by filtrating $100 \mathrm{~mL}$ of sample through the membrane filter with pores of $0,45 \mu \mathrm{m}$ (Sartorius Stedim Biotech, Germany).

After the filtration, the filters were transferred to different agar bases: $\mathrm{m}$ - LES endo agar (Biolife, Italy) for TC and $\mathrm{m}-\mathrm{FC}$ agar (Biolife, Italy) for FC. The incubation period for $\mathrm{TC}$ was 24 hours at $35^{\circ} \mathrm{C}$. FC were incubated 24 hours at $44^{\circ} \mathrm{C}$. For growth of FS we used Slanetz-Bartley agar (Biolife, Italy) and incubated plates 48 hours at $37^{\circ} \mathrm{C}$. After the 48 hours we counted the characteristic colonies on membrane filter and then transferred the membrane filter on Bile aesculine agar (Biolife,
Italy) with the incubation time of 2 hours at $44^{\circ} \mathrm{C}$. After the membrane filtration of sample for PS analysis we placed the filter on Pseudomonas agar base (Biolife, Italy) and incubated the plates 48 hours at $37^{\circ} \mathrm{C}$. Afterwards we counted the fluorescent colonies as a part of the confirmation test by using UV lamp (Hach, Mini UV lamp, Germany) at $\lambda=365 \mathrm{~nm}$. Further identification of isolated Pseudomonas colonies was carried out through applying the biochemical API 20 NE test (bioMérieux, France). 1 $\mathrm{mL}$ of water sample used for determination of Clostridium perfringens were first inoculated into the sterile test tubes then inactivated at $80{ }^{\circ} \mathrm{C}$ for 5 minutes. After the inactivation, the SPS agar (Biolife, Italy) was poured into tubes and samples were incubated 24 hours at $37^{\circ} \mathrm{C}$.

Analytical procedures were tested for reproducibility by means of quadruplicates for random samples. As we determined low standard deviation (around 15\%), analysis were mainly done on single samples.

All collected data were processed in the Excel program (MS Office) where tables and graphics were generated. Differences in TC, FC, FS and PS numbers between the sampling months were tested by one-way ANOVA, followed by Fisher LSD post-hoc test. T-test was used for differences between source area and Prošćansko Lake in previously mentioned variables. All values were $\log (\mathrm{x}+1)$ transformed prior to analysis. One-way ANOVA was done using Statistica 12 program (StatSoft).

\section{RESULTS AND DISCUSSION}

\section{Physicochemical variables}

Physicochemical characteristic of water considering the temperature, $\mathrm{pH}, \mathrm{EC}$ and $\mathrm{DO}$ in the spring area dem- 
Table 1. Mean values and standard deviation of physicochemical characteristics of water at sampling sites in the spring area.

\begin{tabular}{|c|c|c|c|c|c|}
\hline \multirow[t]{2}{*}{ SAMPLING SITE } & \multirow{2}{*}{$\begin{array}{l}\text { DEPTH } \\
(\mathrm{cm})\end{array}$} & \multirow{2}{*}{$\begin{array}{l}\text { TEMPERA- } \\
\text { TURE }\left({ }^{\circ} \mathrm{C}\right)\end{array}$} & \multirow[t]{2}{*}{$\mathrm{pH}$} & \multirow[t]{2}{*}{$\mathrm{EC}\left(\mu \mathrm{S} \mathrm{cm}^{-1}\right)$} & DO \\
\hline & & & & & $\left(\mathrm{mg} \mathrm{L}^{-1}\right)$ \\
\hline WHITE RIVER SOURCE & $11 \pm 2$ & $7.6 \pm 0.4$ & $7.45 \pm 0.14$ & $513 \pm 12$ & $10.55 \pm 0.18$ \\
\hline WHITE RIVER ABOVE THE VILLAGE & $40 \pm 0$ & $7.7 \pm 0.6$ & $7.79 \pm 0.15$ & $503 \pm 11$ & $10.38 \pm 0.31$ \\
\hline WHITE RIVER BELOW THE VILLAGE & $41 \pm 12$ & $7.4 \pm 1.3$ & $7.99 \pm 0.27$ & $490 \pm 11$ & $10.62 \pm 0.67$ \\
\hline BLACK RIVER SOURCE & $10 \pm 0$ & $8.6 \pm 0.5$ & $7.43 \pm 0.05$ & $457 \pm 20$ & $9.93 \pm 0.25$ \\
\hline BLACK RIVER & $104 \pm 26$ & $7.6 \pm 0.4$ & $7.98 \pm 0.04$ & $440 \pm 9$ & $11.04 \pm 0.30$ \\
\hline MATICA RIVER & $76 \pm 8$ & $7.6 \pm 0.6$ & $8.04 \pm 0.07$ & $453 \pm 14$ & $10.63 \pm 0.27$ \\
\hline
\end{tabular}

onstrated high stability throughout this study (Table 1). As is characteristic for springs and headwater streams (19), there were minimal variations within periods of investigation. During the whole period of measurement, the $\mathrm{pH}$ value was between 7.27 - 7.65 for WRs and BRs. The temperature was rather constant and did not exceed 8.2 ${ }^{\circ} \mathrm{C}$ for WRs and $9.3^{\circ} \mathrm{C}$ for BRs, which implies a thorough mixing of seasonal inflow in the aquifer (16). From sampling sites WRs to WRb, the EC value showed a decrease from the highest value of $528 \mu \mathrm{S} \mathrm{cm}^{-1}$ in October (WRs) to the lowest value in March at WRb $\left(473 \mu \mathrm{S} \mathrm{cm}^{-1}\right)$, while the BR had the lowest measured value in March with 430 $\mu \mathrm{S} \mathrm{cm}$. The DO concentration at all sampling sites was not below $9.59 \mathrm{mg} \mathrm{L}^{-1}$.

Contrary to spring area, there were clear seasonal variations in temperature in Prošćansko Lake (Figure 2, 3, and 4). Measurements of water temperature in Prošćansko Lake for this study established the isothermy from the depths of $1 \mathrm{~m}$ to $10 \mathrm{~m}$ in January for the sampling site PLe and from $1 \mathrm{~m}$ to $20 \mathrm{~m}$ for the sampling sites PLm and PLd. Towards the warmer period of the year water temperature increased in surface layer, while at 10 $\mathrm{m}$ depth for sampling site PLe we established the decrease of average 0.6 to $1.8^{\circ} \mathrm{C}$ in regard to $5 \mathrm{~m}$ depth from May

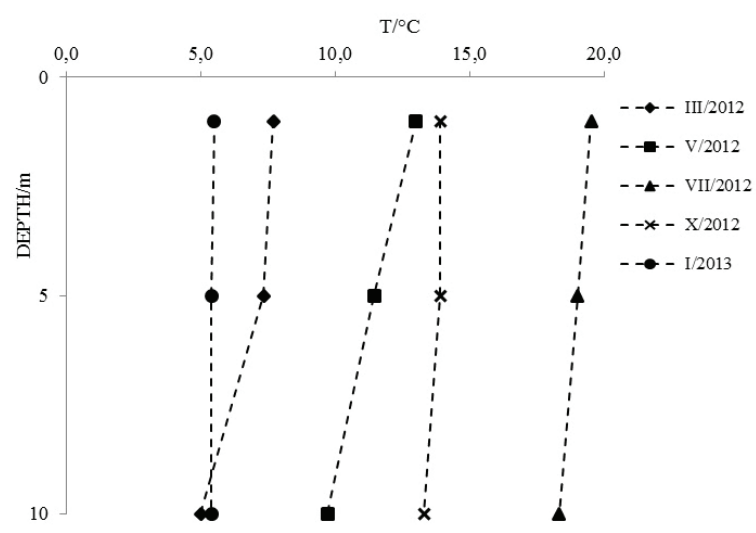

Figure 2. Water temperature at different depths at sampling site PLe during 2012/13. till October (Figure 2). At $10-20 \mathrm{~m}$ of depth for a sampling site PLm, we established the decrease in water temperature (on average $4.8^{\circ} \mathrm{C}$ from May to October) and characteristic thermocline development (Figure 3). At a sampling site PLd, where the Prošćansko Lake is the deepest (around $37 \mathrm{~m}$ ), the more expressed decline in water temperature (by $8.9^{\circ} \mathrm{C}$ ) was observed between the depth of $10 \mathrm{~m}$ and $20 \mathrm{~m}$, which was especially obvious in July (Figure 4). The values of $\mathrm{pH}$ and $\mathrm{EC}$ did not show any important fluctuations in Prošćansko Lake considering either depth or sampling site during the study. Prošćansko Lake has been described by its thermal characteristics as a holomictic lake (due to complete water mixing) and dimictic for its spring and autumn water circulation (20) as it was also proven by the results of this study.

\section{Quantity of fecal indicator bacteria (FIB)}

Decreased number of TC was established in March and May 2012 and in January 2013 at all the sampling sites while their increase was observed in July and particularly October of 2012 (Figure 5). This pattern was also present in the previous studies (21). Source area had significantly higher TC values compared to the lake (t-test,

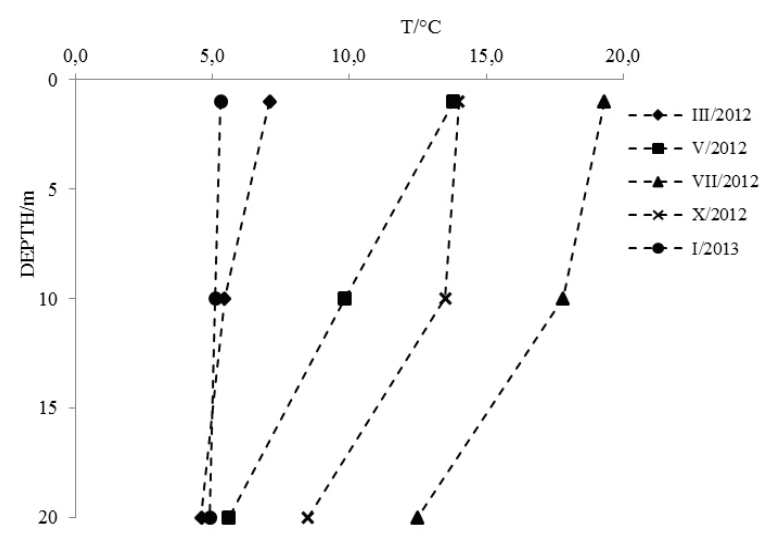

Figure 3. Water temperature at different depths at sampling site PLm during 2012/13. 


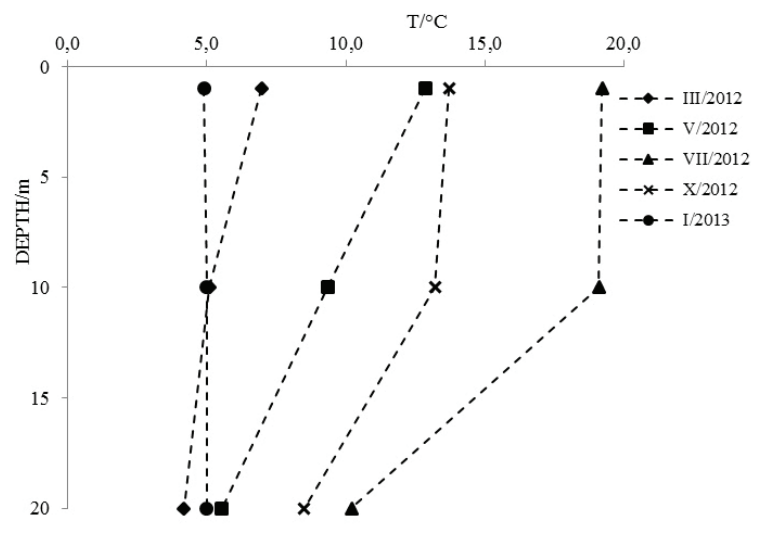

Figure 4. Water temperature at different depths at sampling site PLd during 2012/13.

$\mathrm{t}=3.49, \mathrm{p}<0.001)$. Significant difference in TC was detected between months (one-way ANOVA, $\mathrm{F}_{4,69}=4.842$, $\mathrm{p}<0.01$ ). According to post-hoc LSD test, October values were significantly different from those in March $(\mathrm{p}<0.001)$, May $(\mathrm{p}<0.05)$ and July $(\mathrm{p}<0.01)$, and January differed from March $(\mathrm{p}<0.05)$. Highest determined values were in October with 444 CFU $100 \mathrm{~mL}^{-1}$ at sampling site WRb, and $200 \mathrm{CFU} 100 \mathrm{~mL}^{-1}$ at sampling site WRa. This sudden increase in number of TC was probably due to the increase of rainfall that was measured by pluviometer in October. For this month the measured value was $152 \mathrm{~mm}$ which is almost three times higher than the average monthly value of precipitation $(66.22 \mathrm{~mm})$ in the period of study. Similar case of sudden increase in the number of TC was also established in the Krka National Park and it was due to the heavy rainfall in June (22). Other studies also established the effect of seasonal changes (23) and rainfall on coliform bacteria $(24,25)$.

During this study the number of TC decreased from river Matica to last sampling site in Prošćansko Lake.

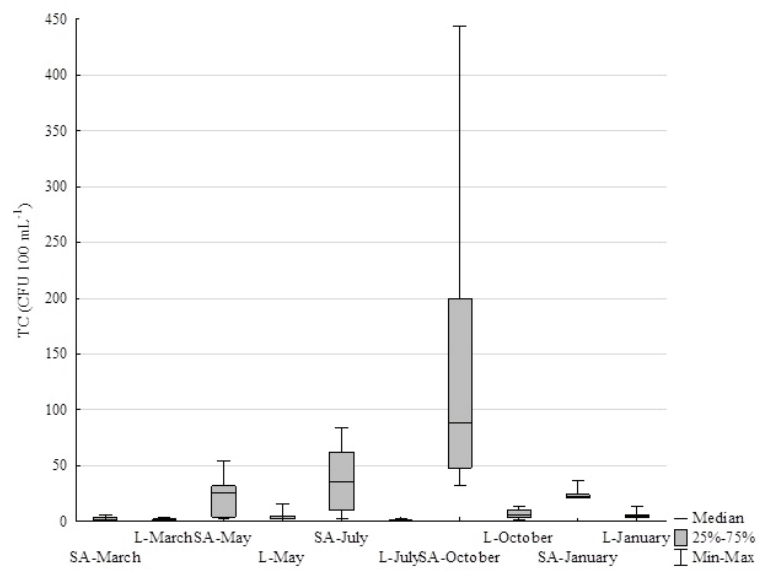

Figure 5. TC in source area (SA) and in Prošćansko Lake (L) during the period of investigation.
Similar observation was established in research on distribution of FIB in Lake Michigan when the pollution plume from the River basin was released into the open waters of lake, and dilution made it difficult to detect FIB (26). The certain number of TC $\left(2-13\right.$ CFU $\left.100 \mathrm{~mL}^{-1}\right)$ was always present at $10 \mathrm{~m}$ of depth on PLe through the whole period of study. The cause could be the resuspension of bacteria in water column because the PLe sampling site is only about $12 \mathrm{~m}$ deep. Almost all sediments in natural waters show evidence of biological activity, and the production of cell exudates by a wide range of biota is of great importance in sediment stability (1). Different researches also proved the sediment as a reservoir and substrate for FIB whose remobilization and transfer depends on different factors (27). We also observed the presence of TC at other two sampling sites in Prošćansko Lake (PLm and PLd) at the depth of 10 to $20 \mathrm{~m}$ in October. One possibility is that water flowing from Matica River (having higher numbers of bacteria) is trapped below thermocline, when the lake is stratified, as the pattern observed in Lake Geneva (28). Similar TC dynamics was also observed for Prošćansko Lake in 2009 (29) where number of TC bacteria had two peaks (June and October).

Considering the number of FC, source area supported higher values compared to the lake ( $\mathrm{t}$-test, $\mathrm{t}=3.79$, $\mathrm{p}<0.001)$. In accordance with TC, sampling site WRb had highest values of FC in May (20 CFU $\left.100 \mathrm{~mL}^{-1}\right)$ and July (30 CFU $100 \mathrm{~mL}^{-1}$ ) (Figure 6). At other sampling sites the numbers of FC were up to $13 \mathrm{CFU} 100 \mathrm{~mL}^{-1}$. There was significant difference in FC between months (one-way ANOVA, $\mathrm{F}_{4,69}=2.655, \mathrm{p}<0.05$ ). Post-hoc LSD test revealed significant difference between January vs. May $(p<0.05)$, July $(p<0.05)$ and October $(p<0.05)$, and March vs. October $(\mathrm{p}<0.05)$. For Prošćansko Lake we did not observe any increase in the number of FC which was in accordance with previous research (29). Only at sampling site $\mathrm{PLe}_{10 \mathrm{~m}}$ in October the number of FC were 10 CFU $100 \mathrm{~mL}^{-1}$. Even though the FC bacteria were pres-

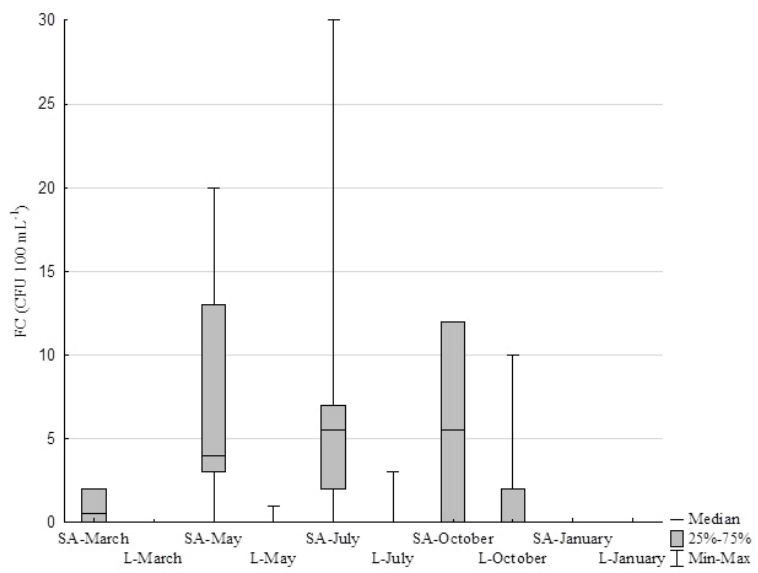

Figure 6. FC in source area (SA) and in Prošćansko Lake (L) during the period of investigation. 
Table 2. FC/FS ratio at sampling sites and through the study period. Site abbreviations as in Fig. 1 .

\begin{tabular}{|c|c|c|c|c|}
\hline $\begin{array}{l}\text { SAMPLING } \\
\text { SITE }\end{array}$ & MAY & JULY & OCTOBER & JANUARY \\
\hline WRs & - & 0.39 & - & - \\
\hline WRa & 0.75 & 0.26 & 4.00 & - \\
\hline WRb & 2.50 & 0.77 & - & - \\
\hline BRs & - & - & - & - \\
\hline BR & 1.25 & 0.27 & 1.00 & - \\
\hline MR & 1.63 & 0.13 & 0.58 & 1.00 \\
\hline $\mathrm{PLe}_{1 \mathrm{~m}}$ & - & - & - & - \\
\hline $\mathrm{PLe}_{5 \mathrm{~m}}$ & 1.00 & - & - & - \\
\hline $\mathrm{PLe}_{10 \mathrm{~m}}$ & - & 0.20 & 1.11 & - \\
\hline $\mathrm{PLm}_{1 \mathrm{~m}}$ & - & - & - & - \\
\hline $\mathrm{PLm}_{10 \mathrm{~m}}$ & - & - & 1.00 & - \\
\hline $\mathrm{PLm}_{20 \mathrm{~m}}$ & - & - & - & - \\
\hline $\operatorname{PLd}_{1 \mathrm{~m}}$ & - & - & - & - \\
\hline $\mathrm{PLd}_{10 \mathrm{~m}}$ & - & - & - & - \\
\hline $\mathrm{PLd}_{20 \mathrm{~m}}$ & - & - & - & - \\
\hline
\end{tabular}

ent at some sampling sites, their absence at others could be caused by possible influence of sunlight which is proven to be the most potent abiotic factor in the inactivation of indicator bacteria $(30,31)$. Furthermore, some studies support the concept that solar UV radiation makes a substantial contribution to the natural purification of water considering the effect of sunlight on coliforms (32).

FS bacteria were also more numerous in source area than in Prošćansko Lake (t-test, t=3.66, $\mathrm{p}<0.001)$. Highest values were in July and October at the sampling site WRb (39 - 70 CFU $100 \mathrm{~mL}^{-1}$ ) (Figure 7, maximal val-

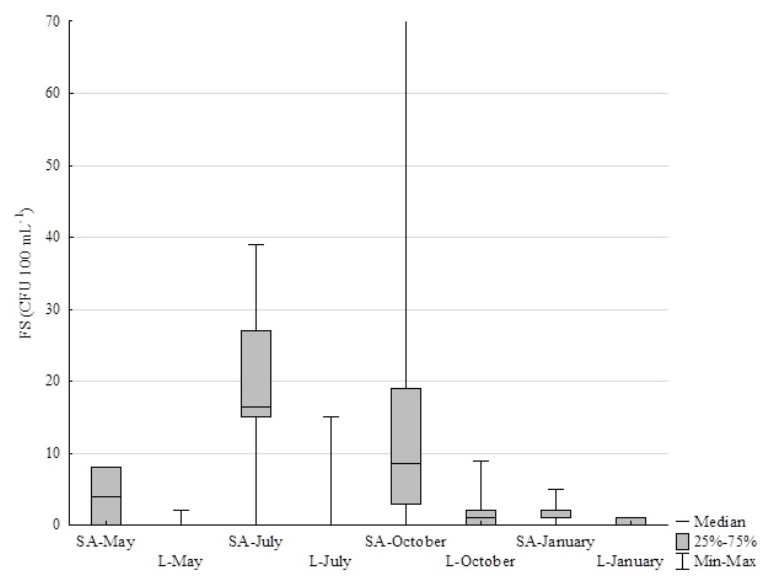

Figure 7. FS bacteria in source area (SA) and in Prošćansko Lake (L) during the period of investigation. ues), while they were for instance not recorded at the sampling site BRs in July. One-way ANOVA did not find significant difference between months in $\mathrm{FS}\left(\mathrm{F}_{3,55}=2.139\right.$, $p>0.05)$. The presence of FS was recorded at most of the sampling sites in Prošćansko Lake except PLd $_{1 \mathrm{~m}}$. The values of FS varied between 1 and $15 \mathrm{CFU} 100 \mathrm{~mL}^{-1}$. The highest recorded value was $15 \mathrm{CFU} 100 \mathrm{~mL}^{-1}$ at $\mathrm{PLe}_{10 \mathrm{~m}}$ in July 2012. Byappanahalli et al. (4) in their review are considering some of the many possible sources of enterococci in environmental waters distinguishing the main ones such as human sources (sewage) and agricultural contributions, which may come directly from animals (cattle defecating in and near the water bodies).

Based on FC/FS ratio we could determine the origin of fecal contamination: the FC/FS ratio $>4$ indicate human origin and the FC/FS ratio $<0.7$ indicate animal origin (33). However, some authors (34) are considering the fact that this ratio is easy to perform and may be useful for determining recent contamination but its disadvantages are variable survival rates of $\mathrm{FS}$ that can alter the ratio. Studies have also found that the FC/FS ratio was difficult to use in agricultural settings (35). Today, there are is a number of different molecular and biochemical methods proposed for BST (Bacterial Source Tracking) (36).

For the most of the sampling sites we could not establish the FC/FS ratio due to the fact that at some sampling sites we did not detected any colonies of FC or FS bacteria. However, in July and at the sampling points WRs, WRa, BR, MR and $\mathrm{PLe}_{10 \mathrm{~m}}$ the FC/FS ratio was less than 0.7 which indicated fecal contamination of animal origin (Table 2).

Bacteria species Pseudomonas aeruginosa was detected at all the sampling sites with highest recorded number in this study for July at sampling site MR (32 CFU 100 $\mathrm{mL}^{-1}$ ) (Figure 8, maximal value). Even though the difference between source area and lake was less pronounced

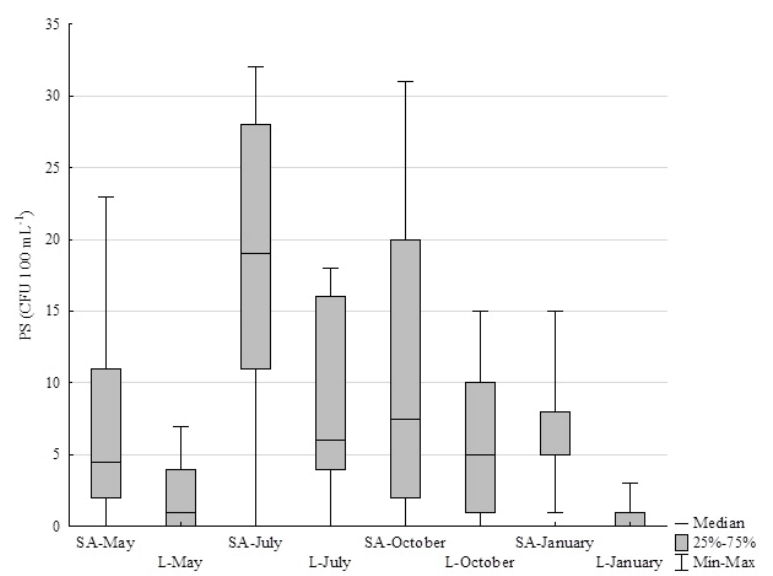

Figure 8. PS in source area (SA) and in Prošćansko Lake (L) during the period of investigation. 
compared to TC, FC and FS (Figs. 5-8), t-test revealed significant difference $(t=3.32, \mathrm{p}<0.01)$. According to oneway ANOVA, there was significant difference between months in PS numbers $\left(\mathrm{F}_{3,55}=3.303, \mathrm{p}<0.05\right)$. July values were significantly different from May values (LSD test, $\mathrm{p}<0.05$ ), and January differed from July (LSD test, $\mathrm{p}<0.01$ ), while other months did not show significant difference. Only at the sampling site $\operatorname{PLd}_{20 \mathrm{~m}}$ we did not recorded the presence of PS in all water samples collected through the period of this study. The API 20 NE biochemical test implemented on isolated colonies on nutrient medium, proved with $99.9 \%$ of certainty that the bacteria species grown on nutrient medium was Pseudomonas aeruginosa.

The bacteria species Clostridium perfringens was not detected in any water samples collected during this study. Earlier research also confirm the negative finding of this bacteria in Prošćansko Lake, while in spring area the average value in the period from 1977 till 1986 was between 0.3 and $1.5 \mathrm{~mL}^{-1}$ (37). However, in mentioned research higher values of Clostridium perfringens were present in sediment and periphyton samples. It was proven by research conducted near sewage outfall in Antarctica that sediment samples retained significantly greater concentrations of $C$. perfringens than in the overlying water column (38).

Physicochemical characteristics of water presented in this study implied certain patterns at all sampling sites: constant temperature, $\mathrm{pH}$ and $\mathrm{EC}$ of karst sources, a decrease in EC value from WRs to WRb, values of DO above $9.59 \mathrm{mg} \mathrm{L}^{-1}$ and temperature measurements at three different sites in Prošćansko Lake confirmed that lake is dimictic. According to the results of microbiological analysis of this study, we can conclude that FIB are present at studied sites, and are especially abundant at a sampling site of White River below the village of Plitvički Ljeskovac (WRb) which is in accordance with previous researches. The increased number of TC and FC was recorded in July and October at sampling sites WRa and WRb in 2012. The increased number of FIB in October at $\mathrm{WRb}$ was probably the result of a heavy rainfall. The calculated FC/FS ratio suggests that at some sampling sites the fecal contamination in water is of animal origin. The quantity of FIB is in decrease from Matica River towards the last sampling site of Prošćansko Lake. This is probably due to dilution of water coming from Matica River. Changes in bacteria number at the estuary of Matica River to Prošćansko Lake, especially at $10 \mathrm{~m}$ of depth implies on the effect of shallowness of a sampling site followed with probable resuspension of lake sediment.

The spring area of Plitvice Lakes National Park is additionally protected through the Management Plan and some of its parts are under special protection, meaning limited tourist visitation in order to reduce anthropogenic influence and to preserve the main sources of rivers.
However, the village Plitvički Ljeskovac, though sparsely populated after the Homeland war, still has the main impact on watercourses of main supply rivers in the $\mathrm{Na}$ tional Park (White and Black River). The reason for that is mainly in the presence of active livestock grazing near watercourses and individual septic systems which are characteristic for households in this area. Due to these facts, this area should always be a subject of intense monitoring in the years to come.

Croatian legislation on water quality and microbiological indicators has been changing over the years. Until the year 2010, the microbiological indicators such as TC, FC and FS were listed in the Regulation of water quality (39) and were, along with other parameters, contributing indicators for determination of water quality for natural waters. In the year 2010 when the new Regulation was acquired, the microbiological indicators were excluded for the first time and therefore it was not possible to interpret their acceptable values in natural waters. Just before the admission to the EU, Croatia acquired new Regulation on water quality standards (40) from which again were excluded all microbiological indicators of water quality, and once again there is no possible legal interpretation of microbiological indicators in natural waters. Even though these bacteria are still an important and certain indicator of potential fecal contamination, we can only confirm or not their presence in natural waters, but we cannot comment on the range of acceptable values according to the current legislative.

\section{REFERENCES}

1. SIGEE D C 2005 Freshwater Microbiology. John Wiley and Sons, LTD, West Sussex, England, p 523

2. APHA 2005 Standard Methods for the examination of water $\&$ wastewater. 21st American Public Health Association (21st ed), Washington

3. DJUIKOM E, NJINE T, NOLA M, SIKATI V, JUNGIA L-B 2006 Microbiological water quality of the Mfoundi River watershed at Yaoundé, Cameroon, as inferred from indicator bacteria of fecal contamination. Environ Monit Assess 122: 171-183 http://dx.doi.org/10.1007/s10661-005-9172-7

4. BYAPPANAHALLI M N, NEVERS M B, KORAJKIC A, STALEY Z R, HARWOOD V J 2012 Enterococci in the Environment. Microbiol Mol Biol Rev 76 (4): 685-706

5. COHEN J, SHUVAL H I 1973 Coliforms, fecal coliforms and fecal streptococci as indicators of water pollution. Water Air Soil Pollut 2 (1): 85-95 http://dx.doi.org/10.1007/BF00572392

6. MENA K D, GERBA C P 1989 Risk Assessment of Pseudomonas aeruginosa in Water. Rev Environ Contam T. 201: 71-115 http://dx.doi.org/10.1007/978-1-4419-0032-6_3

7. DESPAIN S L, GARDNER M V 1949 The occurance of vegetative cells of Clostridium perfringens in soil. J Bacteriol 58 (3): 407-408

8. DESMARAIS T R, SOLO-GABRIELE H M, PALMER C J 2002 Influence of Soil on Faecal Indicator Organisms in a Tidally Influenced Subtropical Environment. Appl Environ Microbiol 68 (3): 1165-1172 http://dx.doi.org/10.1128/AEM.68.3.1165-1172.2002 
9. BROOKES J D, ANTENUCCI J, HIPSEY M, BURCH M D, ASHBOLT N J, FERGUSON C 2004 Fate and transport of pathogens in lakes and reservoirs. Environ Int 30: 741-759

10. TYAGI V K, CHOPRA A K, KAZMI A A, KUMAR A 2006 Alternative microbial indicators of faecal pollution: current perspective. Iran J Environ Health Sci Eng 3 (3): 205-216

11. FORD T D, PEDLEY H M 1996 A review of tufa and travertine deposits of the world. Earth-Sci Rev 41: 117-175 http://dx.doi.org/10.1016/S0012-8252(96)00030-X

12. ŠPOLJARIĆ I, BELANČIĆ A 2011 Obljetnice u 2010. godini 160 godina znanstvenih istraživanja na Plitvičkim jezerima i 49 godina djelovanja Znanstveno-istraživačke postaje. In: Šutić B, Mataija I, Šikić Z, Dujmović A, Ružić V, Brozinčević A (ed) Zbornik radova: Znanstveno-stručni skup Nacionalnog parka Plitvička jezera. Plitvička Jezera, p 356-365

13. STILINOVIĆ B, FUTAČ N 1989 Prilog poznavanju sanitarne vrijednosti nekih opskrbnih voda i jezera na području NP Plitvička jezera 1977.-1986. Plitvički bilten 2: 7-15

14. STILINOVIĆ B, HABDIJA I, DUJMOVIĆ A 2004 Kakvoća vode ekosustava Plitvičkih jezera od 1977.-2003. na temelju bakterioloških analiza. Plitvički bilten 6: 83-92

15. POLŠAK A 2000 Geološki aspekti zaštite Plitvičkih jezera. In: Reprint iz Plitvičkih jezera - čovjek i priroda II., 1974. 50 godina NP PJ, Zagreb, p 226-237

16. SRDOČ D, HORVATINČIĆ N, OBELIĆ B, KRAJCAR I, SLIEPČEVIĆ A 1985 Procesi taloženja kalcita u krškim vodama s posebnim osvrtom na Plitvička jezera. Carsus Iugoslaviae 11 (4-6): 101-204

17. BURŠIĆ I 2013 Popis stanovništva, kućanstava i stanova 2011. Stanovništvo prema spolu i starosti. Statistička izvješća 1468. Državni zavod za statistiku Republike Hrvatske, Zagreb, p 682. [29.06.2015]

18. geoportal.dgu.hr [25.01.2016.]

19. ALLAN J D, CASTILLO M M 2007 Stream Ecology. Springer, Dordrecht, The Netherlands, p 429 http://dx.doi.org/10.1007/978-1-4020-5583-6

20. HABDIJA I, PRIMC-HABDIJA B, BELINIĆ I 1994 Functional community organization of macroinvertebrates in lotic habitats of Plitvice Lakes. Acta Hydroch Hydrob 22 (2): 85-92 http://dx.doi.org/10.1002/aheh.19940220206

21. VURNEK M, BROZINČEVIĆ A, BUŠELIĆ G, ZWICKER KOMPAR G, RUBINIĆ J 2010 Intra-Annual Dynamics of Water Quality Changes in Plitvice Lakes Spring Zone. Proceedings: Balwois Conference, Ohrid

22. BRIŠKI F, SIPOS L, PETROVIĆ M 2000 Distribution of faecal indicator bacteria and nutrients in the Krka river in the region of the Krka National Park. Period biol 102 (3): 273-281

23. HONG H, QIU J, LIANG Y 2010 Environmental factors influencing the distribution of total and fecal coliform bacteria in six water storage reservoirs in the Pearl River Delta Region, China. $J$ Environ Sci 22 (5): 663-668

http://dx.doi.org/10.1016/S1001-0742(09)60160-1

24. KLEINHEINZ G T, MCDERMOTT C M, HUGHES S, BROWN A 2009 Effects of Rainfall on E. coli Concentrations at Door County, Wisconsin Beaches. Int J Microbiol 2009, article ID 876050, p 9

25. WILKES G, EDGE T, GANNON V, JOKINEN C, LYAUTEY E, MEDEIROS D, NEUMANN N, RUECKER N, TOPP E, LAPEN D R 2009 Seasonal relationship among indicator bacteria, pathogenic bacteria, Cryptosporidium oocysts, Giardia cysts, and hydrological indices for surface waters within an agricultural landscape. Water Res 43: 2209-2223

http://dx.doi.org/10.1016/j.watres.2009.01.033
26. MUELLER-SPITZ S R, STEWART L B, VAL KLUMP J, McLELLAN S L 2010 Freshwater Suspended Sediments and Sewage Are Reservoirs for Enterotoxin-Positive Clostridium perfringens. Appl Environ Microbiol 76 (16): 5556-5562

27. POTÉ J, HALLER L, KOTTELAT R, SASTRE V, ARPAGAUS P, WILDI W 2009 Persistance and growth of faecal culturable bacterial indicators in water column and sediments of Vidy Bay, Lake Geneva, Switzerland. J Environ Sci 21: 62-69 http://dx.doi.org/10.1016/S1001-0742(09)60012-7

28. POTÉ J, GOLDSCHEIDER N, HALLER L, ZOPFI J, KHAJEHNOURI F, WILDI W 2008 Origin and spatial-temporal distribution of faecal bacteria in a bay of Lake Geneva, Switzerland. Environ Monit Assess 154(1-4): 337-348 http://dx.doi.org/10.1007/s10661-008-0401-8

29. HABDIJA I, PRIMC B, PLENKOVIĆ-MORAJ A, TERNJEJ I, MATONIČKIN KEPČIJA R, GLIGORA UDOVIČ M, SERTIĆ PERIĆ M, KRALJ BOROJEVIĆ K, DUJMOVIĆ A, BROZINČEVIĆ A, DRAŽINA T, ŽUTINIĆ P, VURNEKM, STILINOVIĆ B 2011 Funkcionalna organizacija planktonske zajednice u jezeru Kozjak i jezeru Prošće kao indikator ekološkog stanja hidrosustava Plitvičkih jezera (Nacionalni park Plitvičkih jezera): studija. Prirodoslovno-matematički fakultet, Zagreb, p 300

30. CHO K W, CHA S M, KANG J-H, LEE S W, PARK Y, KIM J-W, KIM J H 2010 Meteorological effects on the levels of fecal indicator bacteria in an urban stream: A modeling approach. Water Res 44 (7): 2189-2202

31. WHITMAN R L, NEVERS M B, KORINEK G C, BYAPPANAHALLI M N 2004 Solar and Temporal Effects on Escherichia coli Concentration at a lake Michigan Swimming Beach. ApplEnviron Microbiol 70 (7): 4276-4285

http://dx.doi.org/10.1128/AEM.70.7.4276-4285.2004

32. GRIGSBY P, CALKINS J 1980 The inactivation of a natural population of coliform bacteria by sunlight. Photochem Photobiol 31 (3): 291-294

http://dx.doi.org/10.1111/j.1751-1097.1980.tb03721.x

33. GELDREICH E E, KENNER B A 1969 Concepts of Fecal Streptococci in Stream Pollution. J Water Pollut Control Fed, Research Supplement to: 41 (8) Part II: R336-R352

34. SCOTT T M, ROSE J B, JENKINS T M, FARRAH S R, LUKASIK J 2002 Microbial Source Tracking: Current Methodology and Future Directions. Appl Environ Microbiol 68 (12): 5796-5803

35. HOWELL J M, COYNE M S, CORNELIUS P L 1996 Effect of Sediment Particle Size and Temperature on Fecal Bacteria Mortality Rates and the Fecal Coliform/Fecal Streptococci Ratio. J Environ Qual 25 (6): 1216-1220 http://dx.doi.org/10.2134/jeq1996.00472425002500060007x

36. MEAYS C L, BROERSMA K, NORDIN R, MAZUMDER A 2004 Source tracking fecal bacteria in water: a critical review of current methods. J Environ Manage 73: 71-79

37. FUTAČ N 1987 Bakteriološke karakteristike vodenih ekosistema u Nacionalnom parku Plitvička jezera: magistarski rad. Sveučilište u Zagrebu, Centar za poslijediplomski studij, p 168

38. LISLE J T, SMITH J J, EDWARDS D D, McFETERS G A 2004 Occurance of Microbial Indicators and Clostridium perfringens in Wastewater, Water Column Samples, Sediments, Drinking Water and Weddel Seal Feces Collected at McMurdo Station, Antarctica. Appl Environ Microbiol 70 (12): 7269-7276 http://dx.doi.org/10.1128/AEM.70.12.7269-7276.2004

39. Regulation on Water Quality (NN 77/98)

40. Regulation on Water Quality Standards (NN 73/2013 and 151/2014) 